2017-02-10

\title{
Ecological responses to environmental change in marine systems
}

Knights, Antony

http://hdl.handle.net/10026.1/8026

10.1016/j.jembe.2017.01.016

Journal of Experimental Marine Biology and Ecology

Elsevier BV

All content in PEARL is protected by copyright law. Author manuscripts are made available in accordance with publisher policies. Please cite only the published version using the details provided on the item record or document. In the absence of an open licence (e.g. Creative Commons), permissions for further reuse of content should be sought from the publisher or author. 
Ecological responses to environmental change in marine systems

Antony M. Knights ${ }^{1}$, Louise B. Firth ${ }^{2}$, Bayden D. Russell ${ }^{3}$

${ }^{1}$ School of Marine Science and Engineering, Plymouth University, Plymouth, UK

${ }^{2}$ School of Geography, Earth and Environmental Science, Plymouth University, UK

${ }^{3}$ Swire Institute of Marine Science and School of Biological Sciences, The University of Hong Kong, Hong Kong Special Administrative Region, P. R. China.

Corresponding author: Antony M. Knights, antony.knights@plymouth.ac.uk

\section{Background to volume}

Worldwide, the structure of marine communities is being transformed by threats as diverse as climate change, ocean acidification, human introductions of invasive species, and habitat damage, loss or disturbance. Evidence of ecological responses to these threats are increasingly common, manifested in a variety of ways from changes in the behaviour of organisms, to increasing prevalence of disease, changes in the structure, functioning and distribution of species and communities, and efforts to mitigate threats and conserve biodiversity. These responses are occurring across a range of geographic scales, from local, to regional and global, and efforts to understand changes in marine ecosystems are at the forefront of science today. These questions were the focus of the 2015 Aquatic Biodiversity and Ecosystems Conference (ABEC) and this Special Issue presents some of the on-going challenges, solutions and evidence of these responses that emerged from this conference.

\section{Threats to natural systems}

There are numerous threats to marine ecosystems originating from a complex web of human activities, occurring at a range of spatial and temporal scales (Halpern et al. 2008; Knights et al. 2015). Whilst many of these threats are largely manageable, perhaps some of the greatest challenges - habitat loss, climate change, invasive species and ocean acidification - are less so, and the impacts of those threats continue to be at the forefront of scientific research today.

Global temperatures continue to increase at unprecedented rates (IPCC 2014) due to historic and continued greenhouse gas emissions, but steps to mitigate impacts are expected to take at least 50 years before effects are seen (Firth \& Hawkins, 2011). The impacts of climate change on marine ecosystems are wide and varied (Harley et al., 2006; Rosenzweig et al., 2008): reductions in sea ice (Stocker et al., 2013), increased frequency and intensity of storms (Kossin and Vimont, 2007; Smale et al., 2015), extreme weather events (Crisp, 1964; Firth et al., 2011, 2015; Wethey et al., 2011; Wernberg et al., 2016) and 
drought (Diffenbaugh et al., 2015) are particularly obvious examples that have led to catastrophic whole ecosystem changes (Johnson et al., 2011; Russell et al., 2011; Filbee-Dexter and Scheibling, 2014). The implications of global climate change for marine habitats and species are great (Hawkins et al., 2009) but the extent and severity of impacts are yet to be fully revealed (Swart et al., 2015).

Ocean acidification also continues to pose a significant threat to marine ecosystems. In recent years, there has been a burgeoning literature in this field (Gaylord et al., 2015), many of which focused on impacts on early life-history stages (Byrne, 2011; Findlay et al., 2010a; Findlay et al., 2010b) and to a lesser degree, adults (but see Findlay et al., 2009; Gooding et al., 2009; Rodolfo-Metalpa et al., 2011) of plants and animals. Recent studies have suggested historic ocean acidification linked to the Permian-Triassic mass extinction led to the disappearance of $\sim 90 \%$ of marine species (Clarkson et al., 2015). Today, surface ocean hydrogen ion $\left(\mathrm{H}^{+}\right)$concentrations are predicted to increase a further $150 \%$ by 2100 (Stocker et al., 2013). Numerous taxa at first glance appear robust to OA, but when coupled with increased temperature predictions (i.e. ocean acidification-warming scenarios), the persistence of many marine species and associated ecosystem services is less certain (Kroeker et al. 2013).

The introduction of non-native species into new areas, either through intentional (e.g. aquaculture, (Knights et al., 2016; Wethey et al., 2011; Woodin et al., 2014) or unintentional means (ballast water or hull fouling; Wonham et al., 2005; Drake and Lodge, 2007; Mineur et al. 2007) is of continuing concern, especially given the costs associated with the successful establishment of invasive species to ecosystem services (Costanza et al., 1997; Pimentel et al., 2005). It has been estimated that $\sim 10,000$ species are transported globally by these methods alone (Carlton, 1999). The mechanisms of invasion success remain unclear, although evidence suggests the likelihood of establishment may be limited by the existence of intact native species communities (Elton, 1958; Stachowicz et al., 2002; Levine et al., 2004; Arenas et al. 2006). Recently, studies have suggested that the traits and functions of invasives are more similar to those of native species than previously suggested (Wilkie et al., 2012; Zwerschke et al., 2016, but see Borsje et al 2011 for an example of where the non-native outperforms the native), such that the competitiveness (and likelihood of establishment) of invading species is high (Freestone et al., 2011; Freestone et al., 2013). This competitiveness is also likely to increase into the future, at least in part, because invasive species often have broad tolerance for a range of environmental conditions, such as temperature, and so may have a competitive advantage over local species which are better adapted to the local environment (Zerebecki \& Sorte 2011).

As the human population continues to expand (Gerland et al., 2014) and given the propensity to live by the coast, there has been a significant expansion in the use of artificial structures to protect coastal habitats from climate change impacts such as increased erosion. The introduction of artificial structures has had a 
number of impacts including the loss or replacement of natural habitats (Bulleri and Chapman, 2010; Dugan et al., 2011), change in environmental conditions (Airoldi et al., 2005; Wilson and Elliott 2009), breaking down of biogeographic barriers (Dong et al. 2016), and change in community composition including facilitating the establishment and spread of invasive species (Fig. 1, Mineur et al., 2012; Airoldi et al., 2015;

77 Firth et al., 2016).

\section{Ecological Reponses}

The impact of these threats to marine habitats is great, especially as marine habitats from the intertidal zone out to the continental shelf break (and those under greatest threat) are estimated to provide $\sim 43 \%$ of global ecosystem goods (e.g. food, raw materials) and services (e.g. nutrient cycling, carbon sequestration) per year (Costanza et al., 1997). Amelioration of these impacts, in some instances, can be achieved through active management or conservation efforts, or by adaptation by species themselves.

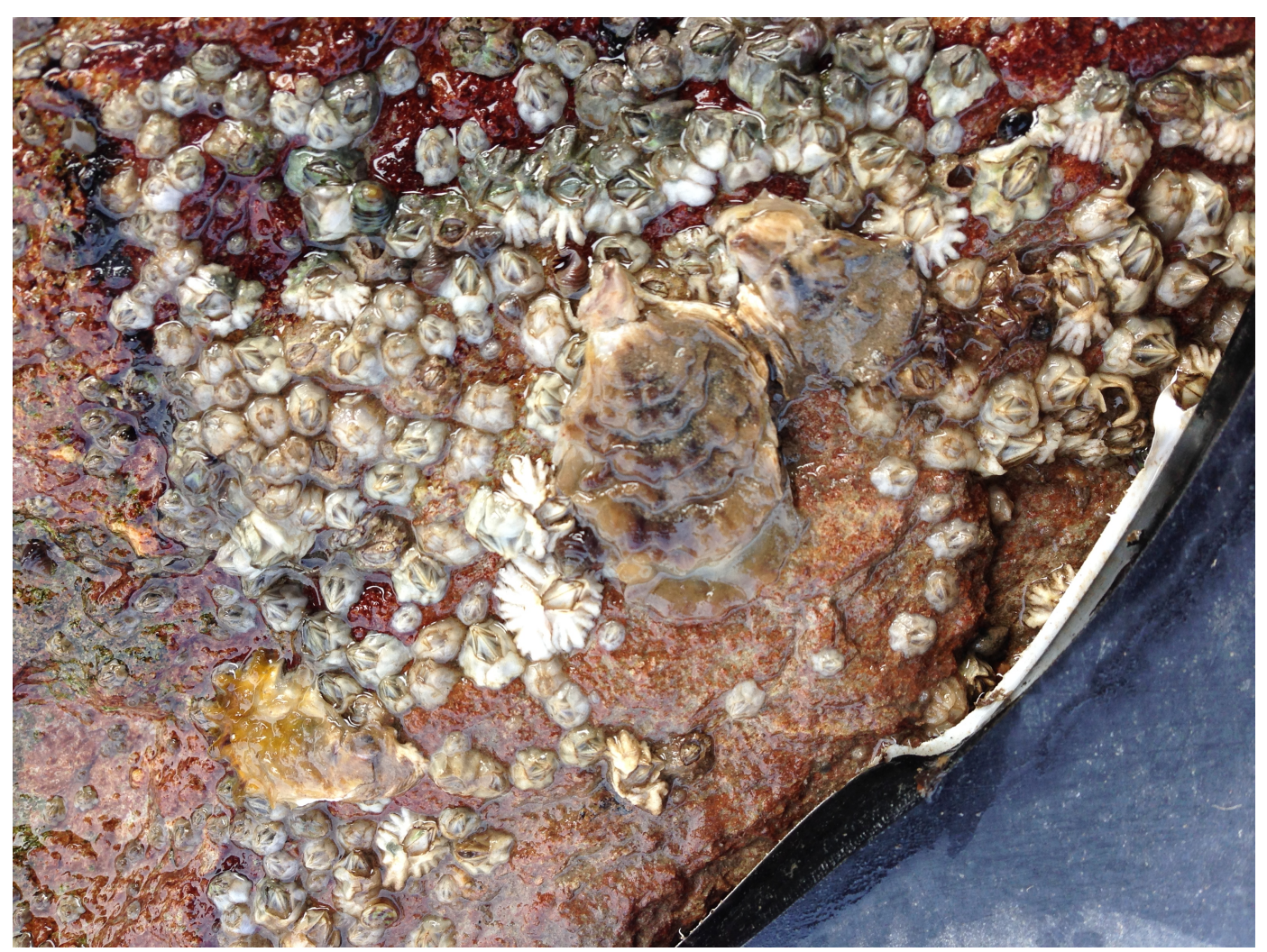

Fig. 1. Proliferation of non-native barnacle (Austrominius modestus) and non-native oyster (Crassostrea gigas) species interspersed with native barnacles, Semibalanus balanoides, on a rocky shore in Plymouth, England. Recruitment has been facilitated by the introduction of artificial substrate on previously open and exposed bedrock. Photo credit: A.M. Knights (unpublished). The ecological responses of marine organisms to environmental change are highly variable both within and between species depending on the relationship between the organism and its environment (Chevin et al., 
2010; Harley et al., 2006). Moritz and Agudo (2013 and references therein) refer to a combination of exposure (at regional or mesoscales) and intrinsic sensitivity (tolerance) as drivers of species vulnerability. They argue that mediation of vulnerability can be achieved by a range of biological responses, including: reductions in body size (Sheridan and Bickford, 2011), changes in abundance, phenological and range shifts (Parmesan, 2006; Parmesan and Yohe, 2003; Mieszkowska et al., 2005, 2014), altered animal behaviour (Sih, 2013), localised adaption (Hansen et al., 2013; Hof et al., 2011; Muir et al., 2016), but may also be characterised by increased incidence of disease and parasites (Hari et al., 2006; Lindgren and Gustafson, 2001) and local extinction (e.g. Pounds, et al. 2005; Poloczanska et al., 2008; Wethey et al., 2011). Variability in species performance, community composition or general response to environmental change at local and regional scales (Muir et al., 2014) is increasingly being shown to affect ecosystem functioning, stability, and ecosystem service provision (McCann, 2000; Naeem, 1998; Tilman et al., 2006) and was an important focus of many talks and posters presented at the ABEC Conference.

\section{Structure of the volume}

This Special Issue volume of the Journal of Experimental Marine Biology and Ecology is a compilation of articles emerging from the Aquatic Biodiversity and Ecosystems Conference (ABEC) held at the University of Liverpool in September 2015. Originally conceived as a follow-up and review of the 1990 Conference PlantAnimal Interactions in the Marine Benthos, ABEC addressed eight themes falling under the broad banner of "Evolution, Interactions and Global change". The themes were: (i) Evolutionary Biology, (ii) Fisheries and Aquaculture, (iii) Dispersal and Connectivity, (iv) General Aquatic Biology, (v) Global Environmental Change, (vi) Food webs and trophic dynamics, (vii) Conservation, Management and Policy, and (viii) Biodiversity, Ecosystem Functioning and Services.

This Special Issue is a compilation of reviews and research articles, each of which, fall under one of these themes. Reviews include the effect of ocean sprawl on ecological connectivity (Bishop et al. 2016) and soft sediment habitats (Heery et al. this issue), ocean acidification impacts on ecosystem service provision in oysters (Lemasson et al. this issue), nutrient flux across the land-sea interface (Moss, this issue) and a global analysis of the role of kelp forests as biogenic habitat formers (Teagle et al. this issue). Research articles include environmental factors affecting host-parasite interactions (Firth et al. this issue), habitat complexity of artificial structures affecting biodiversity (Lavender et al. this issue, Loke et al. this issue), impacts of climate change on intertidal ectotherm behaviour ( $\mathrm{Ng}$ et al. this issue) and larval metamorphosis in response to biofilm cues (Simith et al. this issue). 
agreeing to write this fitting tribute and especially to Helen Hughes for providing much of the information and long-time Roger's right-hand 'man' - she is deserving of tributes of her own!

\section{Acknowledgments}

Compiling this special edition has been a rewarding challenge that couldn't have been achieved without the efforts of all of those who were involved in its preparation and production. We must firstly thank Professor Sandra Shumway, Editor-in-Chief of the Journal of Experimental Marine Biology and Ecology, for giving us the opportunity to produce this special issue. We are also extremely grateful to all the authors for submitting papers to make this exciting issue covering a broad range of topics, and to all the peer-reviewers who helped to draw the contributions together. Without your donated time, we would not have been able to complete this volume. We also wish to thank the staff at the Journal of Experimental Marine Biology and

Ecology for their help in the production of this special volume. But finally, we wish to acknowledge the

legacy and contribution of two great scientists, one who this volume is dedicated to, and another who sadly passed away during the production of this volume. To Professor Roger Hughes and Professor Brian Moss -

\section{References}

Airoldi, L., Abbiati, M., Beck, M.W., Hawkins, S.J., Jonsson, P.R., Martin, D., Moschella, P.S., Sundelöf, A., Thompson, R.C. Åberg, P. 2005. An ecological perspective on the deployment and design of low-crested and other hard coastal defence structures. Coast. Engineer., 52(10), 1073-1087.

Arenas, F., Sánchez, I., Hawkins, S.J. Jenkins, S.R. 2006. The invasibility of marine algal assemblages: role of functional diversity and identity. Ecology, 87(11), 2851-2861.

Bishop, M.J., Mayer-Pinto, M., Airoldi, L., Firth, L.B., Morris, R.L., Loke, L.H.L., Hawkins, S.J., Naylor, L.A., Coleman, R.A., Chee, S.Y., Dafforn, K.A. XXXX. Effects of ocean sprawl on ecological connectivity: impacts and solutions. J. Exp. Mar. Biol. Ecol., THIS ISSUE

Borsje, B.W., van Wesenbeeck, B.K., Dekker, F., Paalvast, P., Bouma, T.J., van Katwijk, M.M. de Vries, M.B. 2011. How ecological engineering can serve in coastal protection. Ecol. Engineer., 37(2), 113-122.

Bulleri, F., Chapman, M.G. 2010. The introduction of coastal infrastructure as a driver of change in marine environments. J. Appl. Ecol., 47(1), 26-35.

Byrne, M. 2011. Impact of ocean warming and ocean acidification on marine invertebrate life history stages: Vulnerabilities and potential for persistence in a changing ocean. Oceanogr. Mar. Biol. Ann. Rev., 49, 1-42.

Carlton, J.T. 1999. The scale and ecological consequences of biological invasions in the World's oceans, In: Sandlund, O.T., Schei, P.J., Viken, A. (Eds.). Kluwer Academic Publishers, 195-212.

Chevin, L.M., Lande, R., Mace, G.M. 2010. Adaptation, plasticity, and extinction in a changing environment: towards a predictive theory. PLoS Biol, 8(4), p.e1000357.

Clarkson, M.O., Kasemann, S.A., Wood, R.A., Lenton, T.M., Daines, S.J., Richoz, S., Ohnemueller, F., Meixner, A., Poulton, S.W., Tipper, E.T. 2015. Ocean acidification and the Permo-Triassic mass extinction. Science, 348(6231), 229-232. 
Costanza, R., d'Arge, R., De Groot, R., Faber, S., Grasso, M., Hannon, B., Limburg, K., Naeem, S., O'neill, R.V., Paruelo, J., Raskin, R.G. 1997. The value of the world's ecosystem services and natural capital. Nature, 387, 253-260.

Crisp, D.J. 1964. The effects of the severe winter of 1962-63 on marine life in Britain. Journal of Animal Ecology, 33(1), 165-210.

Diffenbaugh, N.S., Swain, D.L., Touma, D., 2015. Anthropogenic warming has increased drought risk in California. Proc. Nat. Acad. Sci., 112(13), 3931-3936.

Dong, Y.W., Huang, X.W., Wang, W., Li, Y., Wang, J., 2016. The marine 'great wall' of China: local- and broad-scale ecological impacts of coastal infrastructure on intertidal macrobenthic communities. Diversity and Distributions 22(7), 731-744.

Drake, J.M., Lodge, D.M. 2007. Hull fouling is a risk factor for intercontinental species exchange in aquatic ecosystems. Aquatic Invasions, 2(2), 121-131.

Dugan, J.E., Airoldi, L., Chapman, M.G., Walker, S.J., Schlacher, T., Wolanski, E., McLusky, D. 2011. Estuarine and coastal structures: environmental effects, a focus on shore and nearshore structures. Treatise on estuarine and coastal science, 8, 17-41.

Elton, C.S. 1958. The ecology of invasions by animals and plants. Methuen, London.

Filbee-Dexter, K., Scheibling, R.E. 2014. Sea urchin barrens as alternative stable states of collapsed kelp ecosystems. Mar. Ecol. Prog. Ser. 495, 1-25.

Findlay, H.S., Burrows, M.T., Kendall, M.A., Spicer, J.I., Widdicombe, S. 2010a. Can ocean acidification affect population dynamics of the barnacle Semibalanus balanoides at its southern range edge?. Ecology, 91(10), pp.2931-2940.

Findlay, H.S., Kendall, M.A., Spicer, J.I., Widdicombe, S., 2009. Future high $\mathrm{CO}_{2}$ in the intertidal may compromise adult barnacle Semibalanus balanoides survival and embryonic development rate. Mar. Ecol. Prog. Ser., 389, 193-202.

Findlay, H.S., Kendall, M.A., Spicer, J.I., Widdicombe, S. 2010. Post-larval development of two intertidal barnacles at elevated $\mathrm{CO}_{2}$ and temperature. Mar. Biol., 157(4), 725-735.

Firth, L.B., Knights, A.M., Bell, S.S. 2011. Air temperature and winter mortality: implications for the persistence of the invasive mussel, Perna viridis in the intertidal zone of the south-eastern United States. J. Exp. Mar. Biol. Ecol., 400(1), 250-256.

Firth, L.B., Mieszkowska, N., Grant, L.M., Bush, L.E., Davies, A.J., Frost, M.T., Moschella, P.S., Burrows, M.T., Cunningham, P.N., Dye, S.R., Hawkins, S.J. 2015. Historical comparisons reveal multiple drivers of decadal change of an ecosystem engineer at the range edge. Ecol. Evol., 5(15), 3210-3222.

Firth, L.B., Knights, A.M., Thompson, R.C., Mieszkowska, N., Bridger, D., Evans, A., Moore, P.J., O'Connor, N.E., Sheehan, E.V., Hawkins, S.J. 2016. Ocean sprawl: challenges and opportunities for biodiversity management in a changing world. Oceanography and Mar. Biol. Ann. Rev. 54, 193-269.

Firth, L.B., Grant, L.M., Crowe, T.P., Ellis, J.S., Wiler, C., Convery, C., O'Connor, N.E., XXXX. Factors affecting the prevalence of the trematide parasite Echinostephila patellae (Lebour, 1911) in the limpet Patella vulgata (L.). J. Exp. Mar. Biol. Ecol. THIS ISSUE.

Freestone, A.L., Osman, R.W., Ruiz, G.M., Torchin, M.E., 2011. Stronger predation in the tropics shapes species richness patterns in marine communities. Ecology, 92(4), 983-993.

Freestone, A.L., Ruiz, G.M., Torchin, M.E., 2013. Stronger biotic resistance in tropics relative to temperate zone: effects of predation on marine invasion dynamics. Ecology, 94(6), 1370-1377.

Gaylord, B., Kroeker, K.J., Sunday, J.M., Anderson, K.M., Barry, J.P., Brown, N.E., Connell, S.D., Dupont, S., Fabricius, K.E., Hall-Spencer, J.M., Klinger, T., Milazzo, M., Munday, P.L., Russell, B.D., Sanford, E., Schreiber, S.J., Thiyagarajan, V., Vaughan, M.L.H., Widdicombe, S., Harley, C.D.G., 2015. Ocean acidification through the lens of ecological theory. Ecology 96(1), 3-15. 
Gerland, P., Raftery, A.E., Ševčíková, H., Li, N., Gu, D., Spoorenberg, T., Alkema, L., Fosdick, B.K., Chunn, J., Lalic, N., Bay, G. 2014. World population stabilization unlikely this century. Science, 346(6206), 234-237.

Gooding, R.A., Harley, C.D., Tang, E. 2009. Elevated water temperature and carbon dioxide concentration increase the growth of a keystone echinoderm. Proc. Nat. Acad. Sci., 106(23), 9316-9321.

Hansen, G.J., Ives, A.R., Vander Zanden, M.J., Carpenter, S.R. 2013. Are rapid transitions between invasive and native species caused by alternative stable states, and does it matter?. Ecology, 94(10), 2207-2219.

Hari, R.E., Livingstone, D.M., Siber, R., Burkhardt-Holm, P., Guettinger, H. 2006. Consequences of climatic change for water temperature and brown trout populations in Alpine rivers and streams. Glob. Change Biol., 12(1), 10-26.

Harley, C.D., Randall Hughes, A., Hultgren, K.M., Miner, B.G., Sorte, C.J., Thornber, C.S., Rodriguez, L.F., Tomanek, L., Williams, S.L. 2006. The impacts of climate change in coastal marine systems. Ecology letters, 9(2), 228-241.

Hawkins, S.J., Sugden, H.E., Mieszkowska, N., Moore, P.J., Poloczanska, E., Leaper, R., Herbert, R.J., Genner, M.J., Moschella, P.S., Thompson, R.C. Jenkins, S.R. 2009. Consequences of climate-driven biodiversity changes for ecosystem functioning of North European rocky shores. Marine Ecology Progress Series, 396, 245-259.

Heery, E., Bishop, M.J., Critchley, L., Bugnot, A.B., Airoldi, L., Mayer-Pinto, M., Sheehan, E.V., Coleman, R.A., Loke, L.H.L., Johnston, E.L., Komyakova, V., Morris, R.L., Strain, E., Naylor, L.A., Dafforn, K.A. XXXX. Identifying the consequences of ocean sprawl for sedimentary habitats. J. Exp. Mar. Biol. Ecol., THIS ISSUE

Hof, C., Levinsky, I., Araujo, M.B., Rahbek, C. 2011. Rethinking species' ability to cope with rapid climate change. Glob. Change Biol., 17(9), 2987-2990.

Johnson, C.R., Banks, S.C., Barrett, N.S., Cazassus, F., Dunstan, P.K., Edgar, G.J., Frusher, S.D., Gardner, C., Haddon, M., Helidoniotis, F., Hill, K.L. 2011. Climate change cascades: Shifts in oceanography, species' ranges and subtidal marine community dynamics in eastern Tasmania. J. Exp. Mar. Biol. Ecol., 400(1), 1732.

Knights, A.M., Firth, L.B., Thompson, R.C., Yunnie, A.L., Hiscock, K., Hawkins, S.J. 2016. Regional Studies in Marine Science. In Press

Kossin, J.P., Vimont, D.J. 2007. A more general framework for understanding Atlantic hurricane variability and trends. B Am Meteorol Soc 88, 1767.

Kroeker, K.J., Kordas, R.L., Crim, R., Hendriks, I.E., Ramajo, L., Singh, G.S., Duarte, C.M., Gattuso, J.P., 2013. Impacts of ocean acidification on marine organisms: quantifying sensitivities and interaction with warming. Global Change Biology 19(6), 1884-1896.

Lavender, J.T., Dafforn, K.A., Bishop, M.J., Johnston, E.L. XXXX. Negative interactions between ecosystem engineers lead to the formation of habitat mosaics at small scales. J. Exp. Mar. Biol. Ecol. THIS ISSUE

Lemasson, A.J., Fletcher, S., Hall-Spencer, J.M., Knights, A.M. Linking the biological impacts of ocean acifification on oysters to changes in ecosystem services: a review. J. Exp. Mar Biol. Ecol. THIS ISSUE

Levine, J.M., Adler, P.B., Yelenik, S.G. 2004. A metaanalysis of biotic resistance to exotic plant invasions. Ecol. lett., 7(10), 975-989.

Lindgren, E., Gustafson, R. 2001. Tick-borne encephalitis in Sweden and climate change. Lancet 358, $16-18$.

Loke, L.J.L, Bouma, T.J., Todd, P.A. XXXX. The effects of manipulating microhabitat size and variability on tropical seawall biodiversity: field and flume experiments. J. Exp. Mar Biol. Ecol. THIS ISSUE

McCann, K.S. 2000. The diversity-stability debate. Nature 405, 228-233.

Mieszkowska, N., Kendall, M.A., Hawkins, S.J., Leaper, R., Williamson, P., Hardman-Mountford, N.J., Southward, A.J. 2006. Changes in the range of some common rocky shore species in Britain-a response to climate change?. Hydrobiologia, 555(1), 241-251. 
Mieszkowska, N., Sugden, H., Firth, L.B., Hawkins, S.J., 2014. The role of sustained observations in tracking impacts of environmental change on marine biodiversity and ecosystems. Phil. Trans. R. Soc. Lond. A., 372(2025), 20130339.

Mineur, F., Johnson, M.P., Maggs, C.A., Stegenga, H. 2007. Hull fouling on commercial ships as a vector of macroalgal introduction. Mar. Biol., 151(4), 1299-1307.

Mineur, F., Cook, E.J., Minchin, D., Bohn, K., MacLeod, A., Maggs, C.A., 2012. Changing coasts: marine aliens and artificial structures. Oceanogr, Mar. Biol. Ann. Rev., 50, 189-234.

Moritz, C., Agudo, R. 2013. The future of species under climate change: resilience or decline? Science 341, 504-508.

Moss, B. XXXX. Marine reptiles, birds and mammals and nutrient transfers among the seas and the land: an appraisal of current knowledge. J. Exp. Mar. Biol. Ecol. THIS ISSUE

Muir, A.P., Biek, R., Thomas, R., Mable, B.K. 2014. Local adaptation with high gene flow: temperature parameters drive adaptation to altitude in the common frog (Rana temporaria). Molec. Ecol., 23(3), 561574.

Muir, A.P., Nunes, F.L., Dubois, S.F., Pernet, F. 2016. Lipid remodelling in the reef-building honeycomb worm, Sabellaria alveolata, reflects acclimation and local adaptation to temperature. Sci. Rep., 6.

Naeem, S. 1998. Species redundancy and ecosystem reliability. Conserv. Biol. 12, 39-45.

Ng, T.P.T., Lau, S.L.Y., Seuront, L., Daves, M.S., Stafford, R., Marshall, D.J., Williams, G.A., XXXX. Linking behaviour and climate change in intertidal ectotherms: insights from littorinid snails. J. Exp. Mar. Biol. ECOl. THIS ISSUE

Parmesan, C. 2006. Ecological and evolutionary responses to recent climate change. Annu Rev Ecol Evol S 37, 637-669.

Parmesan, C., Yohe, C. 2003. A globally coherent fingerprint of climate change impacts across natural systems. Nature 421, 37-42.

Pimentel, D., Zuniga, R., Morrison, D. 2005. Update on the environmental and economic costs associated with alien-invasive species in the United States. Ecol. Econ., 52(3), 273-288.

Poloczanska, E.S., Hawkins, S.J., Southward, A.J., Burrows, M.T. 2008. Modeling the response of populations of competing species to climate change. Ecology, 89(11), 3138-3149.

Pounds JA, Fogden MPL, Masters KL (2005) Reponses of natural communities to climate change in a highland tropical forest. A Case Study. In: Hannah, Lovejoy \& Schneider, "Biodiversity and climate change in context" pp. 70-74. Yale University Press, New Haven.

Rodolfo-Metalpa, R., Houlbrèque, F., Tambutté, É., Boisson, F., Baggini, C., Patti, F.P., Jeffree, R., Fine, M., Foggo, A., Gattuso, J.P., Hall-Spencer, J.M. 2011. Coral and mollusc resistance to ocean acidification adversely affected by warming. Nat. Clim. Change, 1(6), 308-312.

Rosenzweig, C., Karoly, D., Vicarelli, M., Neofotis, P., Wu, Q., Casassa, G., Menzel, A., Root, T.L., Estrella, N., Seguin, B., Tryjanowski, P. 2008. Attributing physical and biological impacts to anthropogenic climate change. Nature, 453(7193), 353-357.

Russell, B.D., Harley, C.D., Wernberg, T., Mieszkowska, N., Widdicombe, S., Hall-Spencer, J.M., Connell, S.D. 2011. Predicting ecosystem shifts requires new approaches that integrate the effects of climate change across entire systems. Biol. Lett., p.rsbl20110779.

Sheridan, J.A., Bickford, D. 2011. Shrinking body size as an ecological response to climate change. Nat. Clim. Change 1, 401-406.

Sih, A. 2013. Understanding variation in behavioural responses to human-induced rapid environmental change: a conceptual overview. Anim. Behav. 85, 1077-1088. 
Simith, D.J.B., Abrunhosa, F.A., Diele, K. XXXX. Metamorphosis of the edible mangrove crab Ucides cordatus (Ucididae) in response to benthic microbial films. J. Exp. Mar. Biol. Ecol. THIS ISSUE

Smale, D.A., Yunnie, A.L., Vance, T., Widdicombe, S., 2015. Disentangling the impacts of heat wave magnitude, duration and timing on the structure and diversity of sessile marine assemblages. PeerJ, 3 , p.e863.

Stachowicz, J.J., Fried, H., Osman, R.W., Whitlatch, R.B., 2002. Biodiversity, invasion resistance, and marine ecosystem function: reconciling pattern and process. Ecology, 83(9), 2575-2590.

Stocker, T., et al., 2013. IPCC, 2013: climate change 2013: the physical science basis. Contribution of working group I to the fifth assessment report of the intergovernmental panel on climate change.

Swart, N.C., Fyfe, J.C., Hawkins, E., Kay, J.E., Jahn, A. 2015. Influence of internal variability on Arctic sea-ice trends. Nat. Clim. Change, 5(2), 86-89.

Teagle, H., Hawkins S.J., Moore, P.J., Smale, D.A., XXXX. The role of kelp species as biogenic habitat formers in coastal marine ecosystems. J. Exp. Mar. Biol. Ecol. THIS ISSUE

Tilman, D., Reich, P.B., Knops, J.M. 2006. Biodiversity and ecosystem stability in a decade-long grassland experiment. Nature, 441(7093), 629-632.

Wernberg, T., Bennett, S., Babcock, R.C., de Bettignies, T., Cure, K., Depczynski, M., Dufois, F., Fromont, J., Fulton, C.J., Hovey, R.K., Harvey, E.S. 2016. Climate-driven regime shift of a temperate marine ecosystem. Science, 353(6295), pp.169-172.

Wethey, D.S., Woodin, S.A., Hilbish, T.J., Jones, S.J., Lima, F.P., Brannock, P.M. 2011. Response of intertidal populations to climate: effects of extreme events versus long term change. J. Exp. Mar. Biol. Ecol., 400(1), 132-144.

Wilkie, E.M., Bishop, M.J., O'Connor, W.A. 2012. Are native Saccostrea glomerata and invasive Crassostrea gigas oysters' habitat equivalents for epibenthic communities in south-eastern Australia?. J J. Exp. Mar. Biol. Ecol., 420, 16-25.

Wilson, J.C., Elliott, M. 2009. The habitat - creation potential of offshore wind farms. Wind Energy, 12(2), 203-212.

331 Wonham, M.J., Lewis, M.A., Maclsaac, H.J. 2005. Minimizing invasion risk by reducing propagule pressure: a model for ballast - water exchange. Front. Ecol. Envir., 3(9), 473-478.

Woodin, S.A., Wethey, D.S., Dubois, S.F. 2014. Population structure and spread of the polychaete Diopatra biscayensis along the French Atlantic coast: Human-assisted transport by-passes larval dispersal. Mar. Envir. Res., 102, 110-121.

Zerebecki, R.A. and Sorte, C.J., 2011. Temperature tolerance and stress proteins as mechanisms of invasive species success. PLoS One, 6(4), p.e14806. 